\title{
Masyarakat Indonesia Kontemporer Dalam Pusaran Komunikasi
}

\author{
M. Burhan Bungin \\ Kandidat Ph.D (Communication) \\ College of Arts and Sciences \\ Universiti Utara Malaysia
}

\begin{abstract}
There are 3 points to discuss the Indonesian contemporary society who lives in reformation order. First is urban society with liberalism perspectives, open dan information technology in their hand. Second is structuralist society, who lives and willingness in patron - client/leadership traits. Third is marginal society with less access to education, health system and powerless. In the development of reformation order, with new perspectives anf interpertation, there are some changing in our society, rapidly moved. What implication, also with communication perspectives? Also what is going to happen next, are parts of the discussion in this article.
\end{abstract}

Key word: contemporary society, reformation order, media, communication $\mathcal{E}$ social change

Pendahuluan; Masyarakat Indonesia Kontemporer

Masyarakat Indonesia kontemporer yang dimaksud adalah manusia Indonesia yang hidup setelah era reformasi, yaitu manusia Indonesia yang memiliki 3 (tiga) ciri utama, pertama manusia Indonesia berfaham liberal (MIL) yang hidup di perkotaan, dengan ciri terbuka, memiliki kesadaran menggunakan teknologi informasi di semua bidang kehidupan, memiliki kesadaran berpendidikan yang tinggi, konsumerais, cenderung sekuler dan posmodern serta menjadi bagian dari kapitalis, menjadi bagian dari kaum penguasa, pendukung demokrasi, elite politik dan cenderung burjuis.

Kedua, masyarakat Indonesia strukturalis (MIS) yang hidup di kota dan di pedesaan Indonesia dengan ciri-ciri patuh kepada pimpinan, kesediaan hidup dalam sistem patronklien, menganut salah satu ideologi kemasyarakatan keagamaan, guyub, memiliki akses kedunia pendidikan yang terbatas, umumnya menjadi kelompok pekerja dan cenderung menjadi bagian dari masyarakat modern.

Ketiga, masyarakat Indonesia marginalis (MIM) yang hidup di pelosokpelosok kota, pedesaan dan pulau-pulau terpencil, daerah-daerah perbatasan dengan akses transfortasi dan kamunikasi minimal, kekurang gizi, kurang pendidikan, tradisional dan menjadi korban dari sistem-sistem sosial dan politik 
secara luas, patuh kepada agama dan cenderung tak berdaya.

Secara umum kelompok-kelompok masyarakat di atas berada pada salah satu atau dua ciri utama itu dengan kecenderung kepada salah satu ciri secara dominan.

Hubungan orang-orang yang berada di dalam ketiga ciri utama di atas bersifat fungsional dan cenderung satu ciri mengusai ciri yang lain dimana orangorang pada ciri yang dikuasai cenderung tak berdaya.

Masyarakat Indonesia yang memiliki ciri pertama (MIL) cenderung berada di pusat-pusat kota pemerintahan baik di pusat maupun di daerah dengan dua sistem kekuasaan terhadap ciri lainnya yaitu pertama; menguasai melalui jalur formal, baik pemerintahan maupun birokrasi swasta, kedua; menguasai sistem budaya baik secara ideologi, ekonomi, bahasa dan pendidikan.

Ciri kedua dari masyarakat Indonesia (MIS) tersebar di kota-kota, di pelosok-pelosok daerah, daerah-daerah transisi, daerah-daerah industri, kotakota satelit dengan akses yang luas ke kota-kota metropolis.

Sedangkanciriketiga darimasyarakat Indonesia (MIM) tersebar di daerahdaerah terpencil, pedalaman, pulaupulau terpencil, pulau-pulau terluar Indonesia, daerah-daerah perbatasan yang hampir-hampir tak memiliki akses kepada kota-kota metropolis.

Masyarakat Indonesia kontemporer di semua ciri memiliki kecenderungan mengadopsi kemoderenan dengan berbagai tafsir mereka, suka terhadap budaya populer, menjunjung tinggi gotong royong dalam versi asli maupun persi yang diperbaharui pada ciri-ciri mereka, toleran terhadap hal-hal baru dan kadang melakukan perlawan apabila bertentangan dengan kepentingan mereka.

Salah satu ciri baru dalam masyarakat Indonesia kontemporer, terutama pasca reformasi, adalah sifat agresif masyarakat Indonesia yang membawa mereka kepada tindakan-tindakan anarkhis, mudah melawan hukum dan cenderung tidak patuh kepada penegak hukum, cenderung kurang menghormati sesama orang lain termasuk kurang memiliki sopan-santun, umumnya menyukai tembakau dan kadang kala mengabaikan etika dan akhlak di dalam kehidupan bersama namun disisi lain memiliki kesadaran nasionalisme yang tinggi terhadap Indonesia.

Di bidang komunikasi, masyarakat Indonesia kontemporer memiliki kesadaran berkomunikasi yang tinggi, cenderung menjadi bagian integral dari pasar raya teknologi infomasi, sehingga mendorong transformasi sosial dan nilai-nilai kemoderenan yang sangat cepat (bahkan kadang membabi-buta), membawa masuk masyarakat Indonesia ke dalam pusaran arus transformasi global serta mendorong lunturnya batas-batas teritorial negara, lunturnya nasionalisme dan mendorong dengan cepat lahirnya nilai-nilai global di dalam kekuasaan kapitalisme dunia.

Dari sisi ini, peran media komunikasi di Indonesia telah melahirkan sikap ambivalensia kalangan anak muda Indonesia dengan ideologi ganda, yaitu mencintai Indonesia dengan membabi buta, namun menjadi pendukung dari 
ideologi dunia (lain) yang bahkan mereka tak pernah kenal secara nyata. Dengan kata lain mereka bersedia mati untuk Indonesia dan secara simultan mereka bersedia mati pula untuk tokoh-tokoh favorit mereka di dunia olah raga atau di panggung-panggung budaya populer.

Peran media komunikasi pula telah mengangkat beberapa kesenian tradisional masyarakat Indonesia menjadi budaya populer namun bersamaan dengan itu pula telah membunuh secara sadis budaya tradisional dan banyak kearifan lokal.

Begitu pula secara bersamaan telah menggairahkan dan mengeratkan hubungan-hubungan personal yang telah lama putus, namun juga secara fisik memaksakan hubungan-hubungan itu semakin jauh atau dengan kata lain, media disatu sisi telah menyambung silaturrahim setiap anggota masyarakat Indonesia, namun disisi lain juga memutuskannya tanpa kita sadari.

\section{Perubahan Sosial}

Kata yang pantas kita berikan kepada narasi masyarakat kontemporer seperti di atas adalah bahwa masyarakat Indonesia sedang "berubah". Perubahan sosial masyarakat Indonesia telah mendorong lahirnya new life style terutama di kalangan generasi muda dengan sifatsifat posmodern. Hal ini antara lain disebabkan karena:

\section{a. Booming Media}

Salah satu argumentasi yang kuat dari kalimat "telah terjadi booming media" di Indonesia adalah data tentang tingkat belanja media masyarakat, contohnya belanja pulsa telepon seluler di Indonesia menduduki ranking nomor 2 setelah belanja beras masyarakat Indonesia pada tahun 2009.

Menurut data statistik tercatat bahwa jumlah masyarakat online di seluruh dunia (data diambil tahun 2007) adalah 1,2 milyar dan diperkirakan bertumbuh menjadi 1,8 milyar pada tahun 2010 . Pertumbuhan pengguna internet yang amat pesat nampak di seluruh benua dan benua Asia tercatat memiliki pertumbuhan pengguna internet tertinggi di antara benua-benua lainnya. Pada tahun 2007 pengguna internet aktif di Indonesia telah mencapai 25 juta, dan diperkirakan akan mencapai 150 juta pengguna pada tahun 2012 (http:// www.sentrapromosi.com/iklan/ faktainternet-pengguna-internet-indonesiadan-seluruh-indonesia-booming.html).

Jumlah pengguna seluler di Indonesia hingga Juni 2010 diperkirakan mencapai 180 juta pelanggan, atau 80 persen dari total penduduk Indonesia dan dari 180 juta pelanggan seluler itu sebanyak 95 persen adalah pelanggan prabayar (http://www.antaranews. com/ berita1279093421/ penggunaponsel-indonesia-akan-capai-80-persen).

Data ini tidak terlalu mengagetkan kita karena telah lama kita tahu bahwa telah terjadi booming media di masyarakat Indonesia sebagai akibat dari gelombang informasi yang terjadi sekitar 10-15 tahun terakhir ini. Masyarakat Indonesia menjadi sangat boros menggunakan media terutama seluler sebaliknya mereka tidak pernah sadar telah menjadi pasar kapitalis yang mereka ciptakan sendiri. 


\section{b. Dorongan Atmosfir Politik}

Di bidang politik, masyarakat Indonesia mengalami perubahan yang sangat pesat, setelah terjadi perubahan rezim dari Orde Baru ke Orde Reformasi yang dimulai pada tahun 1997-1998 dan lengsernya Soeharto. Ketika Orde Baru berkuasa, masyarakat Indonesia hidup tenang, aman dan terpenuhi kebutuhan dasar mereka, sebagai akibat dari "politik tangan dingin" Soeharto. Sebagian orang mengatakan keadaan ini sebagai "semu", namun sebagian lain merasa lebih aman dan kelompok-kelompok aktivis demokrasi justru mengatakan keadaan ini sebagai tirani.

Kondisi umum masyarakat Indonesia hidup secara terpimpin, terkontrol dan diawasi. Kendali utama pada orde ini adalah pengengkangan di bidang komunikasi. Arus informasi dari bawah ke atas di atur dan di batasi sementara deras sekali informasi dari atas ke bawa. Akibatnya komunikasi berjalan searah, yaitu dari penguasa ke rakyat sedang dari rakyat ke kepenguasa selalu direkayasa. Kebebasan berbicara menjadi terhambat, kreaktivitas masyarakat yang mendorong perubahan sosial dikontrol, semua harus selaras-serasi dan seimbang dengan penekanan di bidang ekonomi sebagai gerbong perubahan, sedangkan pelaku-pelaku pembangunan bisa dihitung dengan jari, selebihnya hanyalah partisipan. Namun disisi lain perubahan pembangunan di bidang fisik sangat terasa oleh masyarakat, korupsi bisa dikendalikan penyebarannya baik pelaku maupun skala korupsi dan dinamika kepemimpinan terpusat kepada Soeharto. Lembaga negara sangat dihormati, aparat pemerintah sangat berwibawa, namun terkadang lembaga perwakilan rakyat hanyalah pelengkap negara dan secara keseluruhan masyarakat Indonesia berada pada politik kesejahteraan karena itu mereka merasa "aman" hidup di dalam keadaan seperti itu.

Orde Reformasi bangkit setelah Amien Rais dan teman-teman dapat memaksakan Soeharto lengser pada 21 Mei 1998. Semangat waktu itu adalah revolusi walaupun dari mulut aktivis dan mahasiswa menyebutnya reformasi. Semua yang berbau Orde Baru dibumihanguskan, semua yang dibuat Orde Baru di habisi, Golkar harus bubar, TNI di kebiri dan dipaksakan kembali ke barak sementara Polisi mendapat perhatian penuh dari Presiden, lembaga-lembaga negara diganti dan munculnya tokohtokoh politik yang berasal dari aktivis politik dengan berbagai latar belakang.

Orde Reformasi telah mendorong semua perubahan ini, bahwa corongcorong komunikasi yang telah dibuka diawal keruntuhan Orde Baru, justru terkesan membabi-buta di era awal Orde Reformasi ini. Media masa telah menjadi alat politik yang sangat powerfull terutama untuk menyerang kelompok lain. Di bidang politik telah terjadi perubahan besar-besaran ketika lembaga legeslatif dapat "ditempati" oleh siapa saja yang menginginkannya, siapa saja bisa jadi anggota dewan, tak pandang bulu, tukang becak, tukang las, preman, kyai dan sebagainya.

Terjadi gelombang reformasi politik besar-besaran, kaidah-kaidah politik lama telah dibumihanguskan sementara kaidah yang baru belum ada. Beberapa propinsi berteriak merdeka karena tidak percaya lagi dengan pemerintah pusat 
sehingga lahirlah gagasan otonomi daerah, dari pada Indonesia hancur berantakan. Demokrasi terpimpin telah berubah menjadi demokrasi bebas dan desentralisasi, sistem demokrasi perwakilan yang jelas-jelas menjadi salah satu dasar negara telah berubah menjadi sistem demokrasi langsung. Di daerah telah terjadi perubahan yang sangat penting, dimana pimpinan-pimpinan daerah yang berasal dari TNI dan Polisi telah diganti oleh pengusaha, kyai dan tokoh-tokoh preman. Ketiga tokoh ini bersaing dimana-mana untuk menjadi bupati, walikota dan sebagainya.

Di bidang legeslatif terjadi eforia dimana kekuasaannya sangat powerfull, seakan-akan pemerintahan dijalankan melalui kekuasaan legeslatif, korupsi dimana-mana terjadi baik skala maupun pelaku korupsi. Etika politik hancurhancuran, tak ada lawan dan kawan, sementara partai politik hanya di pakai sebagai kendaraan sehingga ongkos politik menjadi sangat mahal bahkan pada perkembang sampai hari ini, fernomena "kutu lompat" yang menjadi aib politik di era sebelumnya menjadi modus perilaku politik yang dilakukan dimana-mana.

Akhir-akhir ini lembaga yudikatif ikut-ikut berubah secara fungsional maupun moral. Lembaga ini yang menjadi tumpuan terakhir masyarakat Indonesia justru ikut hancur-lebur pula. Berbagai kejahatan terstruktur mereka lakukan di atas kejahatan yang mereka tangani.

Lembaga kepresidenan menjadi turun derajat bila dibandingkan dengan era sebelumnya apalagi politik pencitraan yang dilakukan akhir-akhir ini dengan mudah dapat didekonstruksi oleh masyarakat.

Di masyarakat lahir ketidakpuasan melihat tindak-tanduk legeslatif, eksekutif dan yudikatif melengkapi kekecewaan mereka atas malfunction yang terjadi selama ini di tiga lembaga itu.

Kehidupan bernegara terkesan bahwa rakyat kuat maka negara telah lemah, politik telah menjadi raja di semua bidang kehidupan bernegara sementara bidang ekonomi yang dulu menjadi raja saat ini menjadi sangat lemah.

\section{c. Life Style dan Media Malfunction di Masyarakat Indonesia}

Di dalam kehidupan sehari-hari life style masyarakat dikendalikan oleh penguasa-penguasa kapitalis, membuat masyarakat Indonesia menjadi hedonis dan konsumerais. Tekanan-tekanan hidup yang keras di kota, kebanyakan menggiring masyarakat menjadi mudah menghalalkan semua cara untuk kepentingan pemenuhan kebutuhan hidup seperti yang dapat dilihat di dalam kehidupan masyarakat. Hedonisme dan konsumeraisme menjadi tema sentral kehidupan MIL, sedangkan MIS cenderung memasuki kehidupan MIL dan dengan ketidakberdayaannya maka MIM menjadi penonton yang termarginalkan oleh tindak-tanduk MIL dan MIS.

Di bidang media komunikasi, hampir seluruh konten siaran media mewakili kepentingan MIL dan MIS sekaligus menjadikan keduanya menjadi hamba sahaya media. Dengan memanfaatkan eforia kebebasan, media menjadi kaki tangan kapitalis yang bertugas melipatgandakan kekayaan kapitalis sesuka- 
hati mereka. Media telah menjadi media transformasi nilai-nilai buruk dari masyarakat satu ke masyarakat lain, media pula telah menjadi horor di kalangan elite dan kelompok-kelompok masyarakat tertentu. Sedikit sekali ada konten siaran yang ikhlas untuk memperbaiki nilai-nilai yang rusak di masyarakat, karena hampir seluruh konten pemberitaan menjadi bagian model produksi kapitalis, sampai disini, maka media seolah-olah mebela rakyat yang susah, membela orang yang sedang mengalami bencana, membela rakyat kecil yang tertindas dan sebagainya, namun tanpa kita sadari media sedang menjual penderitaan rakyat itu untuk kepentingan kapitalis media.

Kesimpulannya media komunikasi telah menjadi media trsnsformasi nilainilai yang salah di masyarakat, dalam beberapa hal telah terjadi malfunction media yang mendorong life style masyarakat menjadi lebih buruk, mendorong masyarakat agamis menjadi sekuler, dari masyarakat santun menjadi masyarakat yang beringas, sementara yang kita harapkan dari media adalah peran media merubah masyarakat menjadi kritis, merubah masyarakat bodoh menjadi masyarakat yang cerdas dan sebagainya hampir tidak kita dapatkan lagi.

\section{d. Sensifitas Semu}

Sifat lain dari masyarakat Indonesia adalah menjadi masyarakat yang sensitif. Telah terjadi perilaku masyarakat yang luar biasa di dalam era reformasi ini yaitu masyarakat yang gampang tersinggung, masyarakat yang mudah di sulut kemarahannya, masyarakat yang mudah diadu-domba, masyarakat yang gampang dikooptasi kepentinganya dan semacamnya. Namun disisi lain pula terkesan bahwa sensitifitas masyarakat terhadap lingkungan sosial, lingkungan hidup meningkat, kepedulian masyarakat terhadap kehidupan bersama meningkat, namun secara substansial sensifitas ini semu, karena ternyata kebanyakan tidak (jarang) kita temui sifatnya ikhlas. Semua tindakan anggota masyarakat telah ditandai dengan niat yang tidak ikhlas untuk mencari popularitas, untuk mendapat kedudukan, untuk meraih status sosial, untuk memperoleh dukungan dan sebagainya.

Di kalangan masyarakat bawah pun telah terjadi sensifitas semu, perlawanan mereka kepada kelas yang lebih tinggi seakan-akan untuk melawan dominasi elite, namun sesungguhnya adalah untuk mempertahankan kelas mereka. Hal ini seperti yang dapat kita lihat pada keterlibatan masyarakat di semua ciri masyarakat di atas pada bidang politik, bidang sosial, bidang agama, bidang pendidikan, bidang ketahanan nasional dan sebagainya.

\section{e. Metroseksual-Technoseksual}

Di kalangan masyarakat Indonesia liberal (MIL) kata-kata metroseksual dan technoseksual ini menjadi populer, ini adalah salah satu dari gaya hidup konsumerisme. Di wilayah MIL metroseksual dan technoseksual menjadi gaya hidup bergengsi dan semua logika hidup di wilayah ini untuk melayani sifat-sifat metroseksual dan technoseksual. Keadaan ini diciptakan oleh kapitalisme untuk mengalienasi kehidupan masyarakat pada kerja keras mereka dan penyaluran 
stres yang berlebihan. Kesadaran semu yang diciptakan kepitalis adalah menjadikan manusia sebagai hamba sahaya materialisme dan manusia tak sadar kalau mereka telah menjadi subjek yang tak bisa keluar dari sistem produksi kapitalis ini, kecuali melawan.

Dari sinilah lahir banyak peristiwa yang dapat menyusahkan masyarakat, seperti perilaku menyimpang, perilaku a-sosial, perilaku melawan (rebellion) sampai pada perilaku kriminal.

\section{f. Social Networking}

Salah satu hal yang telah berubah di masyarakat adalah interaksi sosial masyarakat Indonesia karena didorong oleh perubahan perilaku komunikasi mereka. Karena akses komunikasi lebih banyak di wilayah MIL dan MIS, maka di dua masyarakat Indonesia ini yang paling banyak berubah, sementara di wilayah MIM cenderung masih menggunakan pola dan struktur hubungan-hubungan sosial lama.

Perubahan model-model social networking di masyarakat Indonesia disebabkan karena perubahan di dunia komunikasi begitu cepat dan perubahan di dunia komunikasi yang cepat karena disebabkan oleh perkembangan teknologi informasi yang sangat pesat.

Dari sisi keberadaan individu di dalam social networking, pada social networking lama, kehadiran individu di dalam hubungan-hubungan itu terjadi secara fisik, total dan memiliki dedikasi moralitas, sementara pada social networking baru, kehadiran individu tidak selalu bersifat fisik namun dapat bersifat virtual, simulakra, tidak perlu harus total dan memiliki dedikasi fungsional.

Dari sisi model komunikasi, pada social networking lama, dominan bersifat satu arah, dua arah atau timbal balik, namun pada model baru, social networking cenderung berbentuk silang dan multi arah. Sedangkan dari sisi kepentingan, kecenderungan social networking masyarakat Indonesia saat ini cenderung bersifat fungsional dan sarat dengan kepentingan.

Dengan demikian interaksi-interaksi semu (palsu) telah berkembang di dalam masyarakat Indonesia kontemporer sebagai model yang paling dominan, sifatnya tidak kekal, sementara, sambil lalu, mudah rusak, mudah dilupakan dan kadang tanpa kesan.

Pandangan-pandangan posmo di dalammasyarakatIndonesiakontemporer bahwa social networking adalah sumber kapital yang dapat memproduksi kapital baru, baik itu sebagai social power capital, political power capital, market power capital dan legitimation power capital.

\section{g. Masyarakat Transformer}

Perubahan sosial yang terjadi di masyarakat Indonesia ini lebih dominan di kendalikan oleh MIL sedangkan MIS dan MIM cenderung menjadi subjek yang dikendalikan. Melihat keadaan ini maka proses transformer di kalangan masyarakat Indonesia lebih banyak terjadi di MIL dan MIS sementara MIM belum dapat sepenuhnya melakukan ini karena keterbatasan mereka.

Di dalam masyarakat Indonesia kontemporer telah terjadi transformasi di semua unsur kebudayaan masyarakat yang meliputi sistem religi, sistem 
pengetahuan, sistem peralatan dan perlengkapan hidup, sistem mata pencaharian dan sistem ekonomi, sistem kemasyarakatan, sistem bahasa, sistem kesehatan, sistempersenjataanyangsecara keseluruhan telah mentransformasikan gaya hidup tradisional kearah gaya hidup modern dan pormodern.

Ciri utama dari perubahan dan transformasi di semua unsur kebudayaan itu adalah pada nilai kapitalisme yang tertanam di dalam semua unsur kebudayaan itu sehingga seakan-akan unsurunsur kebudayaan tidak akan fungsional di dalam masyarakat apabila unsur itu tidak mampu mentransformasi nilainilai lama yang konsumtif menjadi nilainilai baru yang produktif. Jadi unsur kebudayaan apa saja harus dikapatalisasi agar dapat mempertahankan hidupnya lebih lama.

Dengan demikian, agama harus menjadi sumber kapital dari masyarakat dimana agama itu ada, begitu pula sistem kemasyarakatan, bahasa dan sebagainya, terlebih adalah sistem mata pencaharian dan sistem ekonomi itu sendiri. Dengan demikian pula maka unsur-unsur kebudayaan yang tidak mentransformasikan diri menjadi bagian dari kepitalis akan menjadi tak bermanfaat dan akan ditinggal oleh masyarakat.

Di sisi lain masyarakat Indonesia kontemporer lebih transparan dan lebih mudah menerima segala sesuatu yang baru, apalagi hal itu datangnya dari media massa atau dengan kata lain masyarakat Indonesia kontemporer dapat disebut sebagai masyarakat transformer yaitu masyarakat yang gemar mentransformasikan hal-hal yang ia ketahui dan gemar merubah diri dan pandangannya berdasarkan pada hal-hal baru yang ia ketahui itu.

Terutama pada MIL dan MIS, dengan kemampuan menguasai bidang komunikasi, masyarakat Indonesia ini menjadi transformer di dalam masyarakatnya karena apa saja yang dia ketahui dan dia kuasai akan ditransformasikan kepada orang lain.

\section{1) Enterpreneurship dan Technopre- neurship}

Karakter utama dari masyarakat transformer adalah fleksibilitas yang tinggi didalam penguasaan informasi dan dengan kekuasaan itu dia dapat memanfaatkannya sebagai sumber matapencaharian baru.

Di kalangan MIL dan MIS enterpreneurship menjadi kekuatan baru yang sangat kuat di dalam menghadapi kekuatankapitalisme, walaupun terkadang pelaku-pelaku enterpreneuship juga mentransformasi usaha-usaha mereka dikemudian hari menjadi kapitalis baru di masyarakatnya.

Namun paling tidak, semangat enterpreneurship menjadi kekuatan dari dalam untuk membangun masyarakat dengan kekuatan yang mereka miliki sendiri.

Sementara itu dikalangan muda, lahir pula kekuatan baru yang dinamakan technopreneurship yaitu kekuatan ekonomi baru di masyarakat yang memanfaatkan teknologi sebagai kekuatan ekonomi mereka. Banyak anak muda Indonesia sekarang yang meniru keberhasilan Bill Gates dengan mengembangkan situs-situs social networking di dunia maya atau mereka yang berhasil mengembangkan 
teknologi informasi sebagai ruang usaha mereka dan sebagainya.

\section{2) Infotainment}

Transformasi lain yang terjadi di masyarakat adalah media massa telah menjadi masyakat Indonesia sebagai masyarakat infotainment. Pagi, siang, sore, malam bahkan tengah malam, media menyiarkan informasiinformasi tak berguna ini dalam acaraacara infotainment mereka. Terutama di kalang perempuan Indonesia, acara ini menjadi penting dan informasi utama mereka, mereka menjadi sangat khusu dan serius.

\section{3) Masyarakat Tobacco}

Salah satu keberhasilan lain dari pabrik-pabrik rokok di Indonesia adalah mentransformasi kebiasaan merokok kepada seluruh lapisan masyarakat. Bahkan keberhasilan ini juga diikuti dengan keberhasilan menangkal informasi yang mengatakan bahwa merokok itu berbahaya dan sebagainya. Tanpa disadari bahwa masyarakat Indonesia sampai hari ini menjadi masyarakat perokok nomor 3 terbesar di dunia.

Daftar 10 Negara Perokok Terbesar di Dunia (WHO, 2008)

1. China $=390$ juta perokok atau $29 \%$ per penduduk

2. India $=144$ juta perokok atau $12.5 \%$ per penduduk

3. Indonesia $=65$ juta perokok atau $28 \%$ per penduduk ( 225 miliar batang/thn)

4. Rusia $=61$ juta perokok atau $43 \%$ per penduduk

5. Amerika Serikat $=58$ juta perokok atau $19 \%$ per penduduk

6. Jepang $=49$ juta perokok atau $38 \%$ per penduduk

7. Brazil $=24$ juta perokok atau $12.5 \%$ per penduduk

8. Bangladesh $=23.3$ juta perokok atau $23.5 \%$ per penduduk

9. Jerman $=22.3$ juta perokok atau $27 \%$

10. Turki $=21.5$ juta perokok atau $30.5 \%$

\section{Statistik Perokok dari kalangan} anak-anak dan remaja (WHO, 2008)

- Pria $=24.1 \%$ anak $/$ remaja pria

- Wanita $=4.0 \%$ anak $/$ remaja wanita

- Atau 13.5\% anak/remaja Indonesia

Statistik Perokok dari kalangan dewasa (WHO, 2008)

- Pria $=63 \%$ pria dewasa

- Wanita $=4.5 \%$ wanita dewasa

- atau $34 \%$ perokok dewasa

Dengan kata lain jumlah perokok Indonesia sekitar 27.6\%. Artinya, setiap 4 orang Indonesia, terdapat seorang perokok. Angka persentase ini jauh lebih besar dari Amerika saat ini yakni hanya sekitar 19\% atau hanya ada seorang perokok dari tiap 5 orang Amerika. Perlu diketahui bahwa pada tahun 1965, jumlah perokok Amerika Serikat adalah $42 \%$ dari penduduknya. Selama 40 tahun lebih Amerika berhasil mengurangi jumlah perokok dari $42 \%$ hingga kurang dari $20 \%$ di tahun 2008 ini.

\section{4) Posmo-crime}

Transformasi lain di bidang kejahatan telah terjadi di dalam masyarakat 
Indonesia. Kejahatan konvensional telah ditransformer menjadi posmocrime, dimana kejahatan itu ada konstuksi sosial. Kejadian di dunia internasional telah memberi gagasan transformatif terhadap berbagai kejakatan yang terjadi di Indonesia. Lihat saja ketika Amerika mengkonstruksi kejatahan kepada penguasa Taliban di Afganistan dan Irak, bahwa di Afganistan ada penjahat-penjahat yang membom WTC di Amarika. Begitu pula ada penjahat yang bernama Sadam Husein di Irak yang membuat senjata biologis yang sangat membayakan umat manusia. Terakhir dunia baru tahu ternyata semua itu adalah tipu-muslihat Amerika dan temantemannya dengan motif untuk menguasai ladang-ladang minyak di negara-negara itu, inilah yang disebut dengan posmo-crime, dimana kejahatan adalah konstruksi sosial yang dibuat untuk diberikan kepada musuh-musuh mereka.

Di Indonesia hal ini telah berlangsung sejak lama, terutama sejak Orde Reformasi ini. Berbagai kasus besar yang disiarkan media massa kepada kita, hampir seluruhnya adalah posmo-crime, bahwa kejahatan adalah konstruksi sosial yang dibuat untuk mengkriminalkan musuh-musuh mereka. Inilah kejahatan di atas kejahatan, orang yang tak bersalah dapat disalahkan karena kejahatan yang dilakukan oleh sang konstruktor kejahatan.

Negara juga dapat melakukan ini dimana ciri yang paling utama adalah; 1) menciptakan kejahatan untuk diberikan kepada orang lain sebagai musuh-musuh politik; 2) memunculkan sebanyak-banyaknya institusi yang berkaitan dengan penegakan hukum, lalu diamati kinerja mereka. Apabila kinerja mereka merugikan konstruktor, maka lembaga itu dapat dikebiri atau dilemahkan agar menjadi imun terhadap penegakan hukum berikutnya; 3) Ciri lain adalah dengan cara mengambangkan hasil kinerja berbagai institusi penegak hukum dan ciptakan isu-isu baru di bidang penegakan hukum agar kasus yang lama dilupakan orang; 4) ciri terakhir adalah menciptakan predator pada sesama penegak hukum, sehingga tercipta konflik yang berkepanjangan danakhirnyakasus-kasus hukum yang sebenarnya dilupakan masyarakat.

\section{Penutup; Komunikasi Sebagai Panglima}

Saat ini semua orang akan membenarkan apa yang ditesiskan oleh Alvin Toffler, yang pernah ditulisnya di dalam dua buku yang diterbitkan pada tahun 1991 yaitu Third Wave dan Future Shock. Mungkin kita sudah lupa namun saya tak pernah lupa. Buku yang saya kagumi ini menjadi saksi apa yang terjadi saat ini. Ketika gelombang ketiga di dalam buku itu benar-benar menjadi Sunami pada seluruh kehidupan manusia saat ini, kekuatan komunikasi utama yang kita sebut media komunikasi atau yang kita sebut pula media komunikasi massa, telah merubah seluruh cara berfikir manusia. Tanpa mereka sadari telah menjadi bagian terbesar di dalam sistemsistem informasi-komunikasi saat ini, 
mereka menjadi provider sekaligus juga menjadi reciever, mereka menjadi sumber pemberitaaan sekaligus juga menjadi konsumen berita.

Dunia semakin kecil bahkan lebih kecil dari daun kelor ketika seseorang membuka dirinya terhadap transpormasi media komunikasi. Dunia semakin mahal ketika akses komunikasi semakin murah sementara mereka yang menjadi penguasa-penguasa jaringan informasikomunikasi menjadi penguasa-penguasa dunia.

Nah, saat ini, kamunikasi menjadi panglima, apa saja perbincangan di sekitar masyarakat dan perubahan sosial tidak pernah meninggalkan peran komunikasi sebagai lokus utamanya.

Di dalam sosiologi masyarakat modern, kita sadar bahwa komunikasi menjadi kajian-kajian sangat penting dan tak bisa dipisahkan satu dengan lainnya dengan komunikasi. Bahkan secara ekstrim dapat di katakan bahwa apabila kajian-kajian komunikasi kita lepaskan dari sosiologi, maka sosiologi akan kehilangan seluruh kajiannya saat ini. Begitu pula di bidang hukum, ekonomi, kebijakan publik, pendidikan, industri dan teknologi dan lainnya akan bernasib sama seperti sosiologi ketika mereka meninggalkan komunikasi.

Melihat kondisi masyarakat Indonesia kontemporer di dalam pusaran komunikasi yang begini kuat, lembagalembaga pendidikan komunikasi di Indonesia harus melakukan beberapa hal penting; 1) melakukan transformasi teori ke arah lebih progresif dari transformasi fenomena komunikasi itu sendiri; 2) melakukan diversifikasi teoritis dengan melihat arah rumpun ilmu-ilmu sosial dengan membuka diri terhadap kajian-kajian yang sama yang dilakukan pada bidang-bidang ilmu lain; 3) memperbanyak simposium dengan melibatkan berbagai pakar di bidangnya agar mendapat masukan-masukan yang baru sehubungan dengan bidang komunikasi; 4) memberi peluang seluasluasnya agar lahir kajian-kajian baru di bidang komunikasi agar rumpun ilmu ini berkembang luas dan bermanfaat kepada masyarakat banyak.

\section{Daftar Pustaka}

Bungin, B. (2008). Konstruksi Realiti Sosial Media, Iklan Televisi dan Keputusan Konsumen serta Kritik Terhadap Peter L. Berger dan Thomas Luckmann. Jakarta: Prenada Media.

Bungin, B. (2009). Sosiologi Komunikasi. Jakarta: Prenada Media

Jacques, D. (2002). Dekonstruksi Spiritual. Yogyakarta: Jalasutra.

Kaelan. (2009). Filsafat Bahasa Semiotika dan Hermeneutika. Yogyakarta: Paradigma

Kellner, D. (2010). Budaya Media; Cultural Studies, Indentitas dan Politik: Antara Modern dan Postmodern. Yogyakarta: Jalasutra.

Veeger, K. J. (1993). Realitas Sosial. Jakarta: Gramedia

Martinet, J. (2010). Semiologi; kajian Teori Tanda Saussuran Antara Semiologi Komunikasi dan Semiologi Signifikasi. (S. A. Herminarko, Trans.). Yogyakarta: Jalasutra.

McLuhan, M. (1998). The Medium and The Messenger. Combridge; MIT Pres

McLuhan, M. (2001). The Medium is 
The Massage; an Inventory of Effects. Vivian, J. (2007). The Media of Mass Jerome Agel Communication. Boston; Pearson

McQuail, D. (2006). McQuail's Mass Communication Theory. Landon: Sage Publication.

(http: / / www.antaranews.com / berita1279093421/pengguna-ponselindonesia-akan-capai-80-persen).

Samovar, L. A., Porter R. E. \& McDaniel, E. R. (2010). Komunikasi Lintas Budaya. (I. M. Sidabalok, Trans.). Jakarta: Salemba Humanika.

(http://www.sentrapromosi.com/ iklan/ fakta-internet-penggunainternet- indonesia-dan-seluruhindonesia-booming.html). 